\title{
EFFECT OF DIFFERENT GROWING SUBSTRATES ON THE PLANT WATER RELATIONS AND MARKETABLE FRUIT YIELD GREENHOUSE-GROWN TOMATO (Lycopersicon esculentum Mill.)
}

\author{
${ }^{1}$ Edward Borowski, ${ }^{2} J o ́ z e f$ Nurzyński

\begin{abstract}
${ }^{1}$ Department of Plant Physiology, University of Life Sciences in Lublin, Akademicka 13, 20-950 Lublin, Poland ${ }^{2}$ Department of Cultivation and Fertilization of Horticultural Plants, University of Life Sciences in Lublin e-mail: fizjologia.roslin@up.lublin.pl
\end{abstract}

Received: 20.03 .2012

\section{Abstract}

In the period 2009-2011, a study was conducted in a greenhouse, using fertigation, to determine water relations and fruit yield of tomato grown in different substrates. Tomato plants were grown on rockwool slabs, $15 \mathrm{dm}^{3}$ in volume, and on slabs of the same volume made of the following straw chaff: rape straw; rape straw + peat $(3: 1)$; rape straw + pine bark $(3: 1)$; triticale straw; triticale straw + peat $(3: 1)$; triticale straw + pine bark (3:1). 2 tomato plants were grown on each slab, leaving 22 fruit clusters on each plant during the period from February to October. The obtained results showed that water potential, stomatal conductance, transpiration, water saturation deficit, and leaf free proline content in tomato grown on rockwool and on rape or triticale straw chaff substrates did not differ statistically significantly. Also, no significant differences were found in marketable tomato fruit yield and dry matter content in tomato fruits. Peat or pine bark addition to rape or triticale straw substrates had no significant effect on the change in their commercially useful traits. In the opinion of the present authors, substrates made of rape or triticale straw alone, and even more so with the addition of peat or bark, are not inferior in any way to commonly used rockwool.

Key words: tomato, fertigation, organic substrate, water potential, stomatal conductance, transpiration, water saturation deficit, free proline content, dry matter.

\section{INTRODUCTION}

Traditional greenhouse vegetable production carried out for many years in the same place usually results in a reduction in yield of plants caused by soil salinity and its contamination with pathogens. Therefore, modern production technologies are based on the cultivation of plants in various substrates isolated from the parent soil. Growing media used in horticulture can be divided into organic, mineral, and synthetic substra- tes. In Poland vegetable growing on rockwool has been the most popular for a number of years, but peat and perlite are also used for this purpose. In spite of many advantages of rockwool as a growing medium $(\mathrm{C} \mathrm{h} \mathrm{o-}$ chura and Komosa, 1998; Re is et al. 2001), its biggest disadvantage is relatively expensive recycling (B e noit and Ceustermans, 1989) which cannot be done on the spot, at the farm where rockwool was used. Similar problems are associated with the use of perlite as a growing medium. Peat, as an organic substrate, does not cause this type of problems, but its resources are shrinking rapidly, hence the quality of peat substrate is declining and its price is rising.

Thus, there is an urgent need to introduce alternative substrates to vegetable growing which could replace the substrates used hitherto. The requirements set to such substrates include primarily a good supply of water, necessary macro- and micronutrients as well as air to the crop plant throughout the whole growing period. It seems particularly important to maintain a proper balance between water and air which, during the day, must be adjusted to the current temperature and insolation in the greenhouse. A major disturbance in this balance resulting in water deficit causes an decrease in plant water potential ( $\mathrm{Cle}$ a ry et al. 1996; W e g ner and Zi m merm an n, 1998; Zi m mer $\mathrm{m}$ a n n et al. 2000) as well as a decrease in leaf stomatal conductance and transpiration rate $(\mathrm{Cech}$ in, 1998; Congming Lu and Jianhua Zhang, 1998; Flexas et al. 1998; Turner and Thomas, 1998; B orowski et al. 2000; B la mowski et al. 2001; Borowski and Nurzyński, 2007). Under such conditions, plants activate relevant adaptive and protective mechanisms associated with, among others, an increased accumulation of proline in their tissues (Peng et al. 1996; Nakashima 
et al. 1998; J a ved and I kra m, 2008; S zé ke ly et al. 2008; Trovato et al. 2008).

Research conducted in recent years shows that chaffed rye or wheat straw placed in appropriate containers (N u r z y ń s k i , 2006; N u r z y ń s k i , 2006a; B orowski and Nurzyński, 2007; Nurzyńs k i , 2008; N u r z y ń s k i , 2008a) or pressure-formed growing slabs made of such straw (B a b i k , 2006) are the substrate material that can replace the growing media used so far.

The aim of the present study was to determine leaf water relations (negative pressure of water in leaf stalks, water saturation deficit, leaf stomatal conductance and transpiration) and yield of tomato grown in a greenhouse, using fertigation, on rape and triticale straw substrates as well their mixtures with peat and bark. Plants grown on rockwool were the control in the present experiment.

\section{MATERIALS AND METHODS}

The experiments were carried out in an experimental greenhouse of the Department of Cultivation and Fertilization of Horticultural Plants in Lublin in the period 2009-2011. The experimental plant was the tomato Lycopersicon esculentum Mill. cultivar 'Admiro $F_{1}$ ' grown in the period from the beginning of February till the end of October, leaving 22 fruit clusters on each plant, at a density of 2.4 plant per $1 \mathrm{~m}^{2}$. The plants were grown on the following substrates: rockwool; rape straw; rape straw + peat (3:1 vol.); rape straw + pine bark (3:1 vol.); triticale straw; triticale straw + peat (3:1 vol.); triticale straw + pine bark (3:1 vol.). Straw cut into chaff (pieces with a length of ca. $2 \mathrm{~cm}$ ) and a mixture of chopped straw with highmoor peat or pine bark were placed in plastic boxes, $14 \mathrm{~cm}$ high, $8 \mathrm{~cm}$ wide at the bottom, and with a volume of $15 \mathrm{dm}^{3}$. To drain away the excess nutrient solution, holes with a diameter of $8 \mathrm{~mm}$ were bored at a spacing of $10 \mathrm{~cm}$ along the entire length of the box in the lateral side of the box at a height of $1.5 \mathrm{~cm}$ from the bottom. Two tomato plants were planted in each box with $15 \mathrm{dm}^{3}$ of straw, or a mixture of straw with peat or bark, and in each rockwool slab with the same volume $\left(15 \mathrm{dm}^{3}\right)$; hence, one plant had a substrate of $7.5 \mathrm{dm}^{3}$ in volume. The experiment was set up as a completely randomized design in seven replicates.

Nutrients were supplied with water to the root system of each plant using a drip-irrigation system without recirculation. The composition of the applied nutrient solution was the following $\left(\mathrm{mg} \times \mathrm{dm}^{-3}\right)$ : total $\mathrm{N}-210 ; \mathrm{P}-54 ; \mathrm{K}-340 ; \mathrm{Ca}-250 ; \mathrm{Mg}-80 ; \mathrm{S}^{-\mathrm{SO}_{4}}$ - 150; $\mathrm{Cl}-20 ; \mathrm{Fe}-2 ; \mathrm{Mn}-0.95 ; \mathrm{Zn}-0.50 ; \mathrm{B}-0.54$; $\mathrm{Cu}-0.09 ; \mathrm{Mo}-0.09$. EC of the nutrient solution was

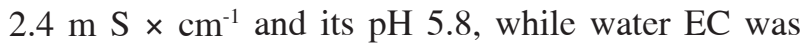

$0.7 \mathrm{~m} \mathrm{~S} \times \mathrm{cm}^{-1}$ and its $\mathrm{pH}$ 7.3. All experimental plants received the same nutrient solution, in the same quantity, and at the same time. During periods of high air temperature, each plant received about $4.2 \mathrm{dm}^{3}$ of the nutrient solution per day in 11-13 doses with $20 \%$ excess of the nutrient solution (overflow).

Measurements of stomatal conductance and transpiration were performed at the flowering stage of the $8^{\text {th }}-9^{\text {th }}$ fruit cluster (21 April 2009), or the $14^{\text {th }}-15^{\text {th }}$ fruit cluster (8 June 2010 and 2011), in the terminal leaflet or the first lateral leaflet of the leaf subtending, respectively, the seventh or twelfth fruit cluster. The measurements were made in 10 replicates using a portable leaf microclimate control system LCA-4, with a PAR irradiance of $1400-1600 \mu \mathrm{mol} \times \mathrm{m}^{-2} \times \mathrm{s}^{-1}$ and a temperature of $30-32^{\circ} \mathrm{C}$ in the recording chamber.

Water potential ( ) was determined in the stalk of the leaf subtending the ninth fruit cluster at an irradiance of ca. $500 \mu \mathrm{mol} \times \mathrm{m}^{-2} \times \mathrm{s}^{-1}$ in morning hours and $1300-1400 \mu \mathrm{mol} \times \mathrm{m}^{-2} \times \mathrm{s}^{-1}$ at midday. The determinations were made in the pressure chamber of a PMS instrument - PMS Instruments Co. (USA) (C l e a r y et al. 1996).

Water saturation deficit (WSD) was determined on the basis of an analysis, made during the spring and autumn period, of the leaves subtending the $10^{\text {th }}$ and $20^{\text {th }}$ fruit cluster sampled at midday and in the morning hours at an irradiance of 1400-1600 and $600-700 \mu \mathrm{mol} \times \mathrm{m}^{-2} \times \mathrm{s}^{-1}$, respectively. To determine water saturation deficit, the leaves, after their fresh mass $\left(m_{1}\right)$ was determined exactly, were immersed for 24 hours in distilled water with a temperature of $20^{\circ} \mathrm{C}$ under weak fluorescent light. After this time, free water on their surface was drained off with filter paper and the leaves were weighed again $\left(\mathrm{m}_{2}\right)$ and subsequently dried to constant mass $\left(\mathrm{m}_{3}\right)$. Water saturation deficit (WSD) was calculated according to the following formula:

$$
\begin{gathered}
W S D \quad \frac{W_{2} W_{1}}{W_{2}} \times 100 \\
\text { where: } \begin{array}{c}
\mathrm{W}_{1}=\mathrm{m}_{1}-\mathrm{m}_{3} \\
\mathrm{~W}_{2}=\mathrm{m}_{2}-\mathrm{m}_{3}
\end{array}
\end{gathered}
$$

Water saturation deficit was determined in 8 replicates.

Proline content in the leaves subtending the 10th fruit cluster was determined according to the method developed by B ate s et al. (1973); this assay was performed in 3 replicates.

Tomato fruits were harvested 2 times a week during a period of six months (May - October). Marketable yield included fruits with a diameter of 4.4-6.0 $\mathrm{cm}$. Dry matter content was determined in the fruits from the fifth and fifteenth cluster using the oven-dry 
method. Sections from 10 ripe fruits (1/4 of the fruit) with a weight of about $20 \mathrm{~g}$ were sampled in triplicate for analysis.

The obtained results were statistically analysed using single classification analysis of variance at the significance level $=0.05$.

\section{RESULTS AND DISCUSSION}

The results presented in Figure 1 show that water potential ( ), as determined in the morning hours, in the leaf stalks of tomato grown in the substrates in question during the study years was high and amounted to $-0.5 \mathrm{MPa}$. But the measurements made on the same day at midday show on average a twice lower value of $(-1.0 \mathrm{MPa})$. This undoubtedly resulted from much higher transpiration caused by a threefold increase in light intensity and about a twofold increase in air temperature (Wagner and Zimmermann, 1998; Zi mmermann et al., 2000). The presented data show that only in the case of rape and triticale straw substrate the average water potential for the study years was slightly lower compared to the other substrates. Such a value of , at high transpiration, shows that the plants were well supplied with water $(\mathrm{Cle}$ ary et al., 1996).

Leaf stomatal conductance and related transpiration also indicate a good supply of water to the tomato plants in all the substrates used (Table 1). In all study years, plants grown on rockwool as well as on triticale straw and rape straw with peat addition showed the highest conductance, while those grown on rape straw and triticale straw alone showed a lower value of this parameter. The average leaf stomatal conductance on the substrates made of both types of straw with the addition of bark was the same and it was higher than on the substrates made of straw alone, but lower than on the straw substrates with the addition of peat. As demonstrated by the results of this study, the level of leaf stomatal opening determined the rate of transpiration, which had been observed earlier by B orowski et al. (2000) as well as by B orow ski and Nurzyński (2007) also in tomato, Cechin (1998) in sorghum, Congming Lu and Jianh u a Zhang (1998) in wheat, Flex as et al. (1998) in grape, Turner and Thomas (1998) in banana, and B la mowski et al. (2001) in cucumber. Thus, similarly as in the case of stomatal conductance, plants grown on rockwool as well as on the substrates made of both types of straw with peat addition showed the highest transpiration throughout the study years. On the other hand, the rate of water evaporation from the leaves of plants growing on rape and triticale straw alone as well as on both these types of straw with the addition of bark was practically the same. However, the differences in both leaf stomatal conductance and the rate of transpiration, which occurs almost entirely through the stomata on a sunny day, were small and within the margin of statistical error. This undoubtedly resulted from the application of fertigation in the present study where the mineral solution was administered in doses according to the change in light intensity. Any differences (though statistically insignificant) in the values of the plant water management parameters in question in plants growing in the substrates used may arise from water retention in these substrates. The excess solution drained away through the holes made in the lateral sides of the boxes at a height of $1.5 \mathrm{~cm}$ from the bottom, thus, above these holes, there was only the amount of mineral solution that was retained by the substrate. Therefore, the data presented in Table 1 demonstrate that rockwool showed almost the same water retention, as both types of straw with the addition of peat. Rape and triticale straw was characterized by the lowest water-retention capacity, and in the case of straw with bark addition this capacity was only slightly higher.

The presented findings are fully confirmed by the data relating to water saturation deficit in tomato leaves (Table 2). This deficit was relatively low in the leaves of plants of all experimental series, but the measurements made in spring showed that it was the highest in plants grown in rape and triticale straw substrates (on average $19.7 \%$ ). The addition of bark to both types of straw decreased the value of the parameter in question to $17.7 \%$, while peat addition to $16.1 \%$. Tomato plants on rockwool showed the lowest water saturation deficit in the leaf tissues $(15.4 \%)$. On the other hand, the measurements made in autumn showed that the average value of the parameter in question was lower by $2.2 \%$ than during the spring period. This indicates that during this period water supply to the tomato leaves was slightly worse, which seems to be attributable to reduced transpiration, resulting from a lower number of leaves on the plants (the leaves beneath the fruiting clusters were removed), about half lower irradiation as well as to a much longer path of water to the leaves.

In all study years, leaf free proline content was very low; its average level in the period 2009-2010 was 42.1 , whereas in 2011 it decreased to $23.5 \mu \mathrm{g}$ $\times \mathrm{g}^{-1} \mathrm{FW}$. Generally, except for the year 2009, tomato plants grown on triticale straw with the addition of bark and on rockwool showed the lowest proline content, whereas those grown on triticale straw demonstrated the highest content. The differences in leaf proline content in tomato grown in the substrates used in the present study were small and statistically insignificant (Table 2). Since the accumulation of free proline in plants occurs under environmental stress conditions, in particular drought and salinity (P e n g 
et al. 1996; N a k a shima et al. 1998; J a ved and Ikra m, 2008; Székely et al. 2008; Trovato et al., 2008), its low level indicates a good supply of water to the plants in all the substrates used.

Marketable tomato fruit yield for the period 2009-2010 averaged $14.2 \mathrm{~kg}$ per plant and it was slightly lower than in $2011(15.1 \mathrm{~kg})$. Except for the year 2009 , plants grown on triticale straw substrate produced the lowest yield, and this yield was only slightly higher for rape straw substrate. The addition of peat to both types of straw had an effect on the increase in yield, and this effect was even greater in the case of bark addition. Plants grown on rape straw with bark addition produced the highest average fruit yield. Nevertheless, the difference between the highest and lowest average fruit yield for the study years was only $1.3 \mathrm{~kg}$ and it was statistically insignificant (Table 3). The usefulness of rape and triticale straw-based substrates has not hitherto been the object of research, but numerous earlier studies show that rye and wheat straw is also suitable for this purpose (B a bik, 2006; N u r z y ń ski , 2006; N u r zy ńs ki , 2006a; B or o w ski and Nurzyński, 2007; N u r z y ń s k i , 2008; N u r z y ń s k i, 2008a).

Likewise in the case of yield, dry matter content in tomato fruits varied slightly both between years and under the influence of the substrates used in the present study (Table 3). In the period 2009-2010, tomato fruits showed higher dry matter content which averaged $5.64 \%$, while in 2011 it was slightly lower $-5.51 \%$. Irrespective of the year, fruits of tomato plants grown on rape straw showed the highest dry matter content $(5.95 \%)$, and also those on triticale straw with the addition of peat $(5.84 \%)$, whereas this parameter was the lowest for those growing on rockwool (5.17\%). In his study on tomato plants grown on rockwool, rye straw, and wheat straw, N u r z y ń s k i (2006) also found dry matter content to be lower in fruits from plants grown on rockwool.

Table 1

Effect of substrate type on stomatal conductance and transpiration in tomato leaves.

\begin{tabular}{|c|c|c|c|c|c|c|}
\hline \multirow{2}{*}{ Substrate } & \multicolumn{3}{|c|}{$\begin{array}{l}\text { Stomatal conductance } \\
\mathrm{molH}_{2} \mathrm{O} \times \mathrm{m}^{-2} \times \mathrm{s}^{-1}\end{array}$} & \multicolumn{3}{|c|}{$\begin{array}{c}\text { Transpiration } \\
\mathrm{m} \mathrm{molH}_{2} \mathrm{O} \times \mathrm{m}^{-2} \times \mathrm{s}^{-1}\end{array}$} \\
\hline & 2009 & 2010 & 2011 & 2009 & 2010 & 2011 \\
\hline Rockwool & 0.28 & 0.26 & 0.28 & 4.85 & 4.32 & 4.65 \\
\hline Rape straw & 0.21 & 0.21 & 0.21 & 4.46 & 4.11 & 4.32 \\
\hline Rape straw + peat & 0.25 & 0.24 & 0.26 & 4.62 & 4.28 & 4.62 \\
\hline Rape straw + bark & 0.24 & 0.22 & 0.24 & 4.14 & 4.21 & 4.48 \\
\hline Triticale straw & 0.22 & 0.21 & 0.20 & 4.25 & 3.95 & 4.30 \\
\hline Triticale straw + peat & 0.28 & 0.24 & 0.26 & 4.76 & 4.19 & 4.58 \\
\hline Triticale straw + bark & 0.24 & 0.21 & 0.23 & 4.32 & 4.06 & 4.29 \\
\hline $\operatorname{LSD}_{0.05}$ & n.s. & n.s. & n.s. & n.s. & n.s. & n.s. \\
\hline
\end{tabular}

Table 2

Effect of substrate type on water saturation deficit (WSD) and free proline content in tomato leaves.

\begin{tabular}{|c|c|c|c|c|c|}
\hline \multirow{3}{*}{ Substrate } & \multicolumn{2}{|c|}{ WSD \% } & \multirow{2}{*}{\multicolumn{3}{|c|}{ Proline $-\mu \mathrm{g} \times \mathrm{g}^{-1} \mathrm{FW}$}} \\
\hline & spring & autumn & & & \\
\hline & \multicolumn{2}{|c|}{2011} & 2009 & 2010 & 2011 \\
\hline Rockwool & 15.4 & 19.2 & 36.8 & 39.7 & 18.9 \\
\hline Rape straw & 18.8 & 20.3 & 37.0 & 56.8 & 22.3 \\
\hline Rape straw + peat & 16.0 & 19.8 & 39.1 & 53.8 & 24.2 \\
\hline Rape straw + bark & 18.2 & 19.4 & 38.8 & 41.2 & 27.1 \\
\hline Triticale straw & 20.7 & 20.7 & 48.3 & 45.1 & 35.4 \\
\hline Triticale straw + peat & 16.3 & 19.1 & 42.7 & 36.1 & 19.1 \\
\hline Triticale straw + bark & 17.3 & 19.2 & 43.4 & 31.4 & 17.9 \\
\hline $\mathrm{LSD}_{0.05}$ & n.s. & n.s. & n.s. & n.s. & n.s \\
\hline
\end{tabular}


Table 3

Effect of substrate type on marketable yield and dry matter content in tomato fruits.

\begin{tabular}{|c|c|c|c|c|c|c|}
\hline \multirow{2}{*}{ Substrate } & \multicolumn{3}{|c|}{ Marketable yield kg $\times$ plant $^{-1}$} & \multicolumn{3}{|c|}{ Dry matter content $\%$} \\
\hline & 2009 & 2010 & 2011 & 2009 & 2010 & 2011 \\
\hline Rockwool & 14.05 & 14.49 & 15.21 & 5.09 & 5.23 & 5.18 \\
\hline Rape straw & 14.64 & 13.06 & 14.99 & 5.64 & 6.17 & 6.03 \\
\hline Rape straw + peat & 14.69 & 13.94 & 14.68 & 5.69 & 5.54 & 5.37 \\
\hline Rape straw + bark & 14.89 & 14.79 & 15.59 & 6.02 & 5.32 & 5.49 \\
\hline Triticale straw & 14.25 & 12.55 & 14.56 & 5.99 & 5.53 & 5.53 \\
\hline Triticale straw + peat & 14.52 & 14.67 & 15.03 & 5.38 & 5.65 & 5.26 \\
\hline Triticale straw + bark & 13.74 & 15.22 & 15.65 & 6.05 & 5.77 & 5.70 \\
\hline $\operatorname{LSD}_{0.05}$ & n.s. & n.s. & n.s. & n.s. & n.s. & n.s. \\
\hline
\end{tabular}

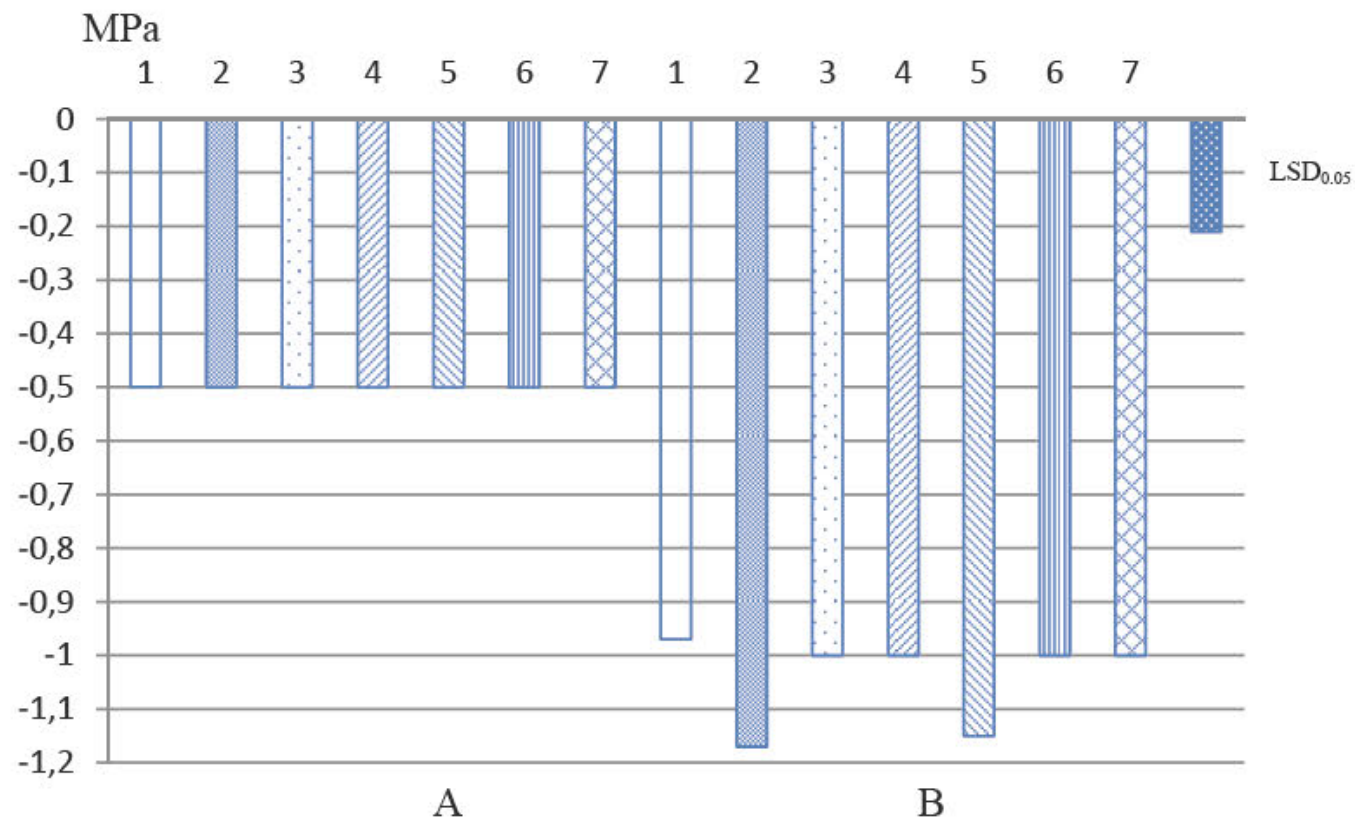

Fig. 1. Leaf water potential ( ) in tomato plants grown on: 1 -rockwool, 2 -rape straw, 3 -rape straw + peat, 4 -rape straw + bark, 5 - triticale straw, 6 - triticale straw + peat, 7 - triticale straw + bark; A - in the morning, B - at midday

\section{CONCLUSIONS}

1. Water relations (water potential, stomatal conductance, transpiration, water saturation deficit) of tomato plants grown in a greenhouse, using fertigation, on rockwool as well as rape and triticale straw substrates did not differ statistically significantly.

2. The addition of other organic materials (highmoor peat, pine bark) to rape and triticale straw substrates did not have a significant effect on their usefulness for greenhouse tomato growing.

3. Tomato plants grown on rockwool and on substrates made of rape and triticale straw as well as their mixtures with peat and bark showed a similar free proline content in leaves.

4. Marketable tomato fruit yield and dry matter content in tomato fruits from plants grown on rockwool and substrates made of rape and triticale straw as well as their mixtures with peat and bark did not differ statistically significantly.

\section{Acknowledgements}

This work was supported by the State Committee for Scientific Research, Poland, grant no. N N310 147935.

\section{REFERENCES}

B a b i k J. 2006. Podłoża organiczne do uprawy ogórka szklarniowego alternatywne dla wełny mineralnej. / Organic substrates for growing greenhouse cucumber alternative to rockwool. Acta Agrophysic. 7 (4): 809-820. (in Polish) 
Bates L.S., Waldren R.R., Teare J.D. 1973. Rapid determination of free proline for water-stress studies. Plant Soil 39: 205-207

Benoit F., Ceustermans N. 1989. Growing tomatoes on recycled polyurethane. Soilless Culture, 5 (2): 3- 10.

Blamowski Z.K., Borowski E., Paczos K. 2001. Wpływ egzogennej spermidyny na rośliny ogórka $(\mathrm{Cu}$ cumis sativus L.) rosnące w warunkach suszy. / The effects of exogenous spermidine on cucumber (Cucumis sativus L.) plants growing under drought conditions. Acta Agrobot. 54 (1): 5-16. (in Polish)

Borowski E., Nurzyński J., Michałojć Z. 2000. Reaction of glasshouse tomato on potassium chloride or sulphate fertilization on various substrates. Ann. UMCS, sect. EEE, 8: 1-9.

Borowski E., Nurzyński J. 2007. Photosynthetic activity of leaves and tomato fruit yield in growing on substrates of cereal straw and its mixtures with other organic substances. Electronic J. Polish Agric. Univ. 10: 2.

Cechin J. 1998. Photosynthesis and chlorophyll fluorescences to hybrids of sorghum under different nitrogen and water regimes. Photosynthetica, 35 (2): 233-240.

Chochura P., Komosa A. 2000. Plonowanie i stan odżywienia pomidora szklarniowego uprawianego w podłożach inertnych. / Yield and nutritional status of greenhouse tomato grown on inert substrates. Ann. UMSC sect. EEE, 8: 283-288. (in Polish)

Cleary B., Laeer J., Hamel J. 1996. Guidelines for measuring plants moisture stress with a pressure chamber. PMS Instrument Company. 480 SW, Airport Avenue, Corvallis, USA.

Congming Lu., Jianhua Zhang 1998. Effect of water stress on photosynthesis chlorophyll fluorescence and photoinhibition in wheat plants. Aust. J. Plant Physiol. 25: 883-892.

Flexas J., Escalona J.M., Medrano H. 1998. Down - regulation of photosynthesis by drought under field conditions in grapevine leaves. Aust. J. Plant Physiol. 25: 893-900.

Javed F., I k r a m S. 2008. Effect of sucrose induced osmotic stress on callus growth and biochemical aspects of two wheat genotypes. Pak. J. Bot. 40(4): 1487-1495.

Nakashima K., Satoh R., Kiyosue T., Yamaguchi-Shinozaki K. 1998. A gene encoding proline dehydrogenase in not only induced by proline and hypoosmolarity, but is also developmentally regulated in the reproductive organs of Arabidopsis. Plant Physiol. 118: 1233-1241.

Nurzyński J. 2006. The yielding of greenhouse tomato grown in straw and rockwool. Folia Hort. 18/2: 17-23.

Nurzyński J . 2006a. Plonowanie i skład chemiczny pomidora uprawianego w szklarni w podłożach ekologicznych. / Yield and chemical composition of greenhouse tomato grown in ecological substrates. Acta Agropysic. 7(3): 681-690. (in Polish)

Nurzyński J. 2008. Słoma jako alternatywa dla podłoży inertnych. / Straw as an alternative to inert substrates.
Mat. Konf. „Nowe podłoża organiczne w uprawie roślin ogrodniczych pod osłonami”. Komitet Nauk Ogrodniczych PAN W-wa, 5-6. (in Polish)

Nurzyński J. 2008a. Przydatność słomy jako podłoże w uprawie pomidora w szklarni. / Usefulness of straw as a substrate in greenhouse tomato growing. Mat. Konf. „Aktualne trendy w uprawie i nawożeniu roślin ogrodniczych" SGGW W-wa, 15-16. (in Polish)

Peng Z., Lu Q., Verma D.P. 1996. Reciprocal regulation of ${ }^{1}$-pyrroline-5-carboxylate synthetase and proline dehydrogenase genes controls proline levels during and after osmotic stress in plants. Mol. Gen. Genet. 253: 334-341.

Reis M., Inacio H., Rosa A., Caco J., Monteiro A. 2001. Grape mare compost as an alternative growing media for greenhouse tomato. Acta Hortic. 554: 75-81.

Székely G., Ábrahám E., Cséplo Á., Rigo G., Zsigmond L., Csiszár F., Strizhov N., Jásik J., Schmelezer E., Koncz C., Szabados L. 2008. Duplicated P5C5 genes of Arabidopsis play distinct roles in stress regulation and developmental control of proline biosynthesis. Plant J. 53: 11-28.

Trovato M., Mattioli R., Costantino P. 2008. Multiple roles of proline in plant stress tolerance and development. Rendiconti Lincei 19: 325-346.

Turner D.W., Thomas D.S. 1998. Measurements of plant and soil water status and their association with leaf gas exchange in banana (Musa ssp.): a laticiferous plant. Sci. Hortic. 77: 177-193.

Wagner L., Zimmermann U. 1998. Simultaneous recording of xylem pressure and trans root potential in roots of intact glycophytes using a novel xylem pressure probe technique. Plant Cell Environ. 21: 849-865.

Zimmermann U., Wagner H.J., Schneider H. 2000. Water ascent in plants: the ongoing debate. Elsevier Science, 5 (4): 145-146.

\section{Wpływ różnych podłoży na stosunki wodne i plon handlowy owoców pomidora (Lycopersicon esculentum Mill.) uprawianego w szklarni}

\section{Streszczenie}

W latach 2009-2011 przeprowadzono badania w szklarni z zastosowaniem fertygacji, dotyczące określenia stosunków wodnych i plonu owoców pomidora uprawianego na różnych podłożach. Rośliny rosły na matach $\mathrm{z}$ wełny mineralnej o pojemności $15 \mathrm{dm}^{3}$ i matach o analogicznej pojemności przygotowanych z sieczki: słomy rzepakowej, słomy rzepakowej + torf (3:1), słomy rzepakowej + kora sosnowa (3:1), słomy pszenżyta, słomy pszenżyta + torf (3:1), 
słomy pszenżyta + kora sosnowa (3:1). W każdej macie rosły 2 rośliny, prowadzone na 22 grona w okresie od lutego do października. Uzyskane wyniki wykazały, że potencjał wody, przewodność szparkowa, transpiracja, deficyt zawartości wody i zawartość wolnej proliny $\mathrm{w}$ liściach pomidora uprawianego na wełnie mineralnej i podłożach przygotowanych $\mathrm{z}$ sieczki słomy rzepakowej lub pszenżyta nie różniły się w sposób istotny statystycznie. Nie stwierdzono także istotnych różnic w wysokości plonu handlowego owoców pomidora i w zawartości w nich suchej masy. Dodatek torfu lub kory sosnowej do podłoży przygotowanych ze słomy rzepakowej lub pszenżyta nie wpłynął w istotny sposób na zmianę ich wartości użytkowych. W opinii autorów podłoża przygotowane z samej słomy rzepakowej lub słomy pszenżyta, a tym bardziej z dodatkiem torfu lub kory w niczym nie ustępują powszechnie stosowanej wełnie mineralnej. 
